\title{
Canoparmelia pustulifera, a new species of Parmeliaceae containing perlatolic acid from Southern Brazil
}

\author{
Michel Navarro Benatti', Suzana Maria de Azevedo Martins², Carlo Vos ${ }^{3}$ \& Emily Holt ${ }^{4}$ \\ 1 Instituto de Botânica de São Paulo, Nucleo de Pesquisas em Micologia, Avenida Miguel Estéfano 3687, Água Funda, São Paulo, SP, Brasil. \\ michelbenatti@yahoo.com.br \\ 2 Fundação Zoobotânica do Rio Grande do Sul, Museu de Ciências Naturais, Tv. Vileta, 1 - Jardim Botânico, Porto Alegre, RS, Brasil. sue. \\ azemartins@gmail.com \\ ${ }^{3}$ University of Utah, Utah Valley University, 800 West University Parkway \\ Orem, UT 84058 USA.carlo.vos@uvu.edu \\ ${ }^{4}$ University of Northern Colorado, Campus Box 92, Greeley, CO 80639 USA. \\ emily.holt@unco.edu
}

Recebido em 29.III..2016

Aceito em 08.VIII.2017

DOI 10.21826/2446-8231201772215

ABSTRACT - Canoparmelia pustulifera Benatti, S.M. Martins, Vos \& Holt is a new lichen species discovered during a trip near Parque Estadual de Itapuã, in Rio Grande do Sul State, Southern Brazil. The species is the second pustulate Canoparmelia species discovered after C. albomaculata, and contains perlatolic acid and several other still-undetermined medullary substances.

Palvras-chave: Canoparmelia caroliniana, maculae, pustulae, soredia

RESUMO - Canoparmelia pustulifera, uma nova espécie de Parmeliaceae contendo ácido perlatólico do Sul do Brasil. Canoparmelia pustulifera Benatti, S.M. Martins, Vos \& Holt é uma nova espécie de líquen descoberta durante uma expedição próxima ao Parque Estadual de Itapuã, Estado do Rio Grande do Sul, Região Sul do Brasil. É a segunda espécie pustulada de Canoparmelia descoberta, após C. albomaculata, e contém ácido perlatólico além de diversas outras substâncias medulares indeterminadas .

Keywords: Canoparmelia caroliniana, maculas, pustulas, soredios

\section{INTRODUCTION}

The genus Canoparmelia Elix \& Hale. is characterized within the parmelioid lichens by the narrow ( $\leq 5 \mathrm{~mm}$ wide), usually rotund lobe apices, often irregular maculae (mostly distinct at younger parts), absence of pseudocyphellae and marginal cilia, black to brown lower surface, simple scattered rhizines, small $(\leq 14 \times 10 \mu \mathrm{m})$, hyaline ellipsoid ascospores, and usually bifusiform to baciliform conidia ( $\leq$ $10 \times 1 \mu \mathrm{m})$ (Brodo et al. 2001, Nash \& Elix 2002). There are currently about 45 species known worldwide (Nash \& Elix 2002), with a total of eight cited for Brazil (Marcelli 2004). The list of Brazilian Canoparmelia has been modified in the past decade, adding several novelties from recently published works (Marcelli \& Ribeiro 2002, Benatti et al. 2008, Canêz et al. 2009, Marcelli et al. 2011), while some species were circumscribed into different genera, Crespoa (Lendemer \& Hodkinson 2012, Benatti \& Lendemer 2014) or Parmelinella (Benatti 2012). The medullary chemistry is variable, as in other Parmeliaceae genera, with several chemosyndromes, also including a number of unknown substances.
Canoparmelia pustulifera is a new pustulate species, the second described for the genus with this characteristic. This new species was discovered during a trip to a site in the vicinity of Parque Estadual de Itapuã, Rio Grande do Sul State, Southern Brazil. The Park is a protected area of the Pampa Biome, extensive grassland plains with sparse shrubs and trees, also representative of Argentina and Uruguay (Roesch et al. 2009).

\section{MATERIAL AND METHODS}

The granitic hills are a typical rocky formation found at the Parque Estadual de Itapuã and several Porto Alegre municipality areas. The vegetation cover is quite varied, ranging from grasslands to hill-slope forests of the Atlantic rainforest. Rocky outcrops are commonly found. A comprehensive and detailed overview of the vegetation can be found at Rio Grande do Sul (1996). Among the different landscapes at the locality are forested granitic hills with rocky fields (the site of the collection), several beaches, sand dunes, resting wood, swamps, lagoons, and some islands. The climate is characterized as subtropical humid (Cfa) accordingly to Köppen classification, with an 
average annual rainfall of $1,300 \mathrm{~mm}$ and a mean annual temperature of $17.5^{\circ} \mathrm{C}$ (Rio Grande do Sul 1996).

Morphological characters were studied using standard stereoscopic and compound light microscopes. Anatomical sections were made using a razor blade by hand. The specimen examined lack apothecia and pycnidia. Chemical constituents were checked by spot tests with potassium hydroxide (K), sodium hypochlorite (C) and para-phenylenediamine $(\mathrm{P})$, and also examined under $\mathrm{UV}$ light (360 nm). Since a single, relatively small specimen was available for observation, chemical constituents were first analyzed using HPLC, following the same procedures described in detail at Benatti et al. (2013), followed by TLC, solvent A.

\section{RESULTS}

Canoparmelia pustulifera Benatti, S.M. Martins, Vos \& Holt $s p$. nov.

MycoBank: MB 815446

(Figs 1-3)

Diagnosis: Similar to Canoparmelia albomaculata Ribeiro \& Marcelli, but the pustulae have an irregular, non-isidioid aspect, eventually eroding into coarse soredia at mature stages, and thallus with a black lower surface.

Holotype: BRAZIL, RIO GRANDE DO SUL, Viamão, Parque Estadual do Itapuã vicinity, Sítio Pedacinho do Morro, on tree bark, 3058'24,7'S 5058'57,1', 26.IX.2014 M.N. Benatti \& S.M.A. Martins 3579 (HAS).

Thallus fragments up to $4.5 \mathrm{~cm}$ wide, membranaceous, corticolous, greenish gray, lobate. Lobes irregularly branched, (0.5-) 1.0-2.5 (-3.5) mm wide, contiguous to overlapping laterally, adnate, loosely attached. Apices \pm plane to slightly bent downwards, \pm rounded. Margin flat to subcanaliculate, subcrenate to irregular, entire to incised, often sublacinulate, eciliate, axils oval or irregular. Upper surface smooth, continuous at young lobes gradually becoming transversally cracked on older parts. Maculae laminal, usually distinct at younger lobes becoming less apparent at older parts, \pm linear to irregular, occasionally originating fissures. Adventitious marginal lobules somewhat common on the margins of older lobes, short, simple to rarely irregularly branched, flat, $0.1-0.5$ $\times 0.2-0.6 \mathrm{~mm}, \pm$ rounded, underside concolorous with the lower marginal zone. Soredia always originating from pustules that erode at mature stages, \pm coarse, subgranular, rarely darkening, forming tiny blackish spots, true soralia not formed. Pustules in the form of irregular, eventually extensive clustered blisters, laminal but commonly disposed along the submargins, or subapical at older lobes, eroding at mature stages into soredia. Isidia absent. Cilia absent. Medulla white, without $\mathrm{K}+$ purple pigmented spots. Lower surface black, shiny, smooth or slightly veined at distal parts turning rugose at the center, moderately rhizinate. Marginal zone shiny, brown and attenuate, $0.5-3.0 \mathrm{~mm}$ wide, smooth to partially venate, occasionally weakly papillate, becoming rhizinate in the transition zone towards the center. Rhizines brownish near the margins to black elsewhere, simple, $0.1-0.6 \times$ ca. $0.05 \mathrm{~mm}$, irregularly grouped, scarce to frequent. Apothecia and pycnidia not seen.

Spot reactions: upper cortex $\mathrm{K}+$ yellow, $\mathrm{UV}-$; medulla $\mathrm{K}-, \mathrm{C}-, \mathrm{KC}+$ ephemeral pale pink, $\mathrm{P}-, \mathrm{UV}+$ pale bluish.

HPLC/TLC: atranorin, perlatolic acid, many unidentified minor substances and a major, unidentified Rf 2 substance at TLC, Solvent A.

Comments: Canoparmelia pustulifera is the second pustulate species described (the first being C. albomaculata) for the genus. It is morphologically similar to the isidiate C. caroliniana (Nyl.) Elix \& Hale, but is instead pustulate with the pustules eventually eroding into soredia. By direct comparison, the pustulae of $C$. albomaculata have a different aspect, resembling coralloid isidia or even polisidiangia found on several Physciaceae species, which is much taller and larger in comparison and rarely eroding into soredia. The medullary chemistry of the three species is similar, what indicates that they could possibly be associated.

At first we considered that the specimen could belong to C. albomaculata (Marcelli \& Ribeiro 2002), but comparison with the specimens at SP, including the type, showed several differences. Canoparmelia albomaculata is currently known only for some localities from Minas Gerais State in Brazil. The locality where C. pustulifera was found is over $1500 \mathrm{~km} \mathrm{~S}$, and no other pustulate specimens of Canoparmelia were found. It is a more rigid, pale-colored lichenwith pustules, morphologically different from other related taxa.

The disposition of the pustules is similar to those in $C$. albomaculata, although in C. pustulifera they can be found laminally as well. The lower cortex in C. albomaculata is overall pale brown (with some few occasional dark brown spots), not black with brown margins, and the rhizines are evenly distributed, although they are scarce. Even when rarely forming soredia, the pustules of $C$. albomaculata originate from the apical portion of the pustules, while the pustules of $C$. pustulifera erode near entirely into soredia except for their basal portion. Canoparmelia albomaculata also differs by its more dichotomously branched lobes and blackish-lined margins devoid of lacinules or lobules.

As stated in the literature (e.g. Hale 1976, Brodo et al. 2001, Nash \& Elix 2002, Spielmann \& Marcelli 2008, Benatti 2014), C. caroliniana differs from both C. pustulifera and $C$. albomaculata by being an isidiate species, not forming pustules of any kind, nor its isidia ever evolving into soredia. It also has an overall black lower cortex with a brown marginal zone, but some specimens occasionally present variable, irregularly distributed brown spots. 

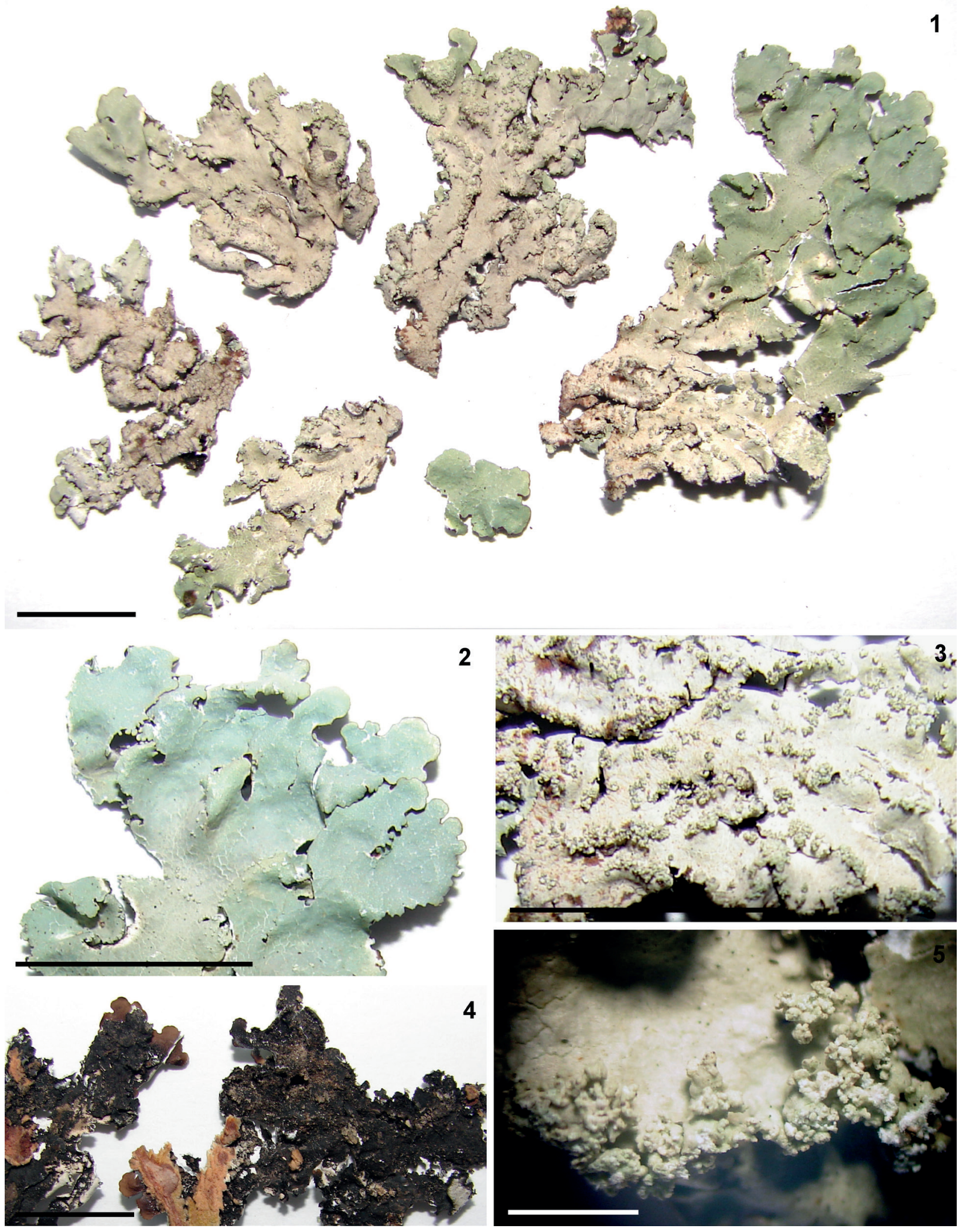

Figs. 1-5. Holotype of Canoparmelia pustulifera. 1. Thallus; 2. Detail of the distal lobes with maculae and lack of cilia; 3. Detail of the pustule disposition on the lobes; $\mathbf{4}$. Detail of the black lower cortex and narrow brown marginal zone; $\mathbf{5}$. Detail of pustules, partially eroding into soredia. Scale bars: Figs. 1-4 =1 cm; Fig. $5=1 \mathrm{~mm}$. 
We used HPLC and found many minor substances, making it difficult to describe the complex of substances present in C. pustulifera. Even the peak for perlatolic acid was not clearly distinct, so we used TLC (solvent A) to confirm the compounds thought to be present.

Comparing our novel species with materials of $C$. caroliniana, we found they shared most the same chemistry (at least major compounds), as we could clearly identify atranorin and perlatolic acid. Besides several minor substances, TLC also revealed an unidentified major spot ( RF 2) which did not correlate with other related substances in this group, thus its identify remains unknown.

The single specimen found is corticolous, although the area where it was collected was a rocky field. The type locality is a cliffy area in moderately open vegetation between 50-110 $\mathrm{m}$ altitude, close to the northern portion of the Guaiba Lake (River).

The species is named after the many irregular, clustered blister-like pustules that are produced over the upper cortex.

\section{ACKNOWLEDGEMENTS}

The authors wish to thank Marcelo Pinto Marcelli for comments and suggestions, and the reviewers for critical revision of the manuscript.

\section{REFERENCE}

Benatti, M.N. 2012. Canoparmelia cinerascens belongs in the genus Parmelinella (Parmeliaceae, lichenized Ascomycota). Opuscula Philolichenum 11:26-30.

2014. Pequenas espécies de Parmeliaceae (Ascomycota)

eciliadas no Parque Estadual da Cantareira, Estado de São Paulo, Brasil: gêneros Canoparmelia e Crespoa. Rodriguésia 65:587-597.
Benatti, M.N., Gernert, M. \& Schmitt, I. 2013. Parmotrema hydrium, a new species of Parmeliaceae in southeastern Brazil. Acta Botanica Brasilica 27:810-814.

Benatti, M.N. \& Lendemer, J.C. 2014. Canoparmelia scrobicularis belongs to the genus Crespoa (Parmeliaceae, lichenized Ascomycota). Brittonia 66:287-291.

Benatti, M.N., Marcelli, M.P. \& Elix, J.A. 2008. Canoparmelia sanguinea, a new Parmeliaceae from Brazil. Mycotaxon 106:435-439.

Brodo, I.M., Sharnoff, S.D. \& Sharnoff, S. 2001. Lichens of North America. Yale University Press, New Haven. 828p.

Canêz, L.S., Marcelli, M.P. \& Elix, J.A. 2009. New Brazilian species of Canoparmelia with medullary olivetoric, anziaic, and sekikaic complexes. Mycotaxon 110:465-472.

Hale, M.E. 1976. A monograph of the lichen genus Pseudoparmelia Lynge (Parmeliaceae). Smithsonian Contributions to Botany 31:1-62.

Lendemer, J.C. \& Hodkinson, B.P. 2012. Recognition of the Parmelia crozalsiana group as the genus Crespoa. North American Fungi 7:1-5.

Marcelli, M.P. 2004. Checklist of lichens and lichenicolous fungi of Brazil. Version 1. Available at: http://www.biologie.uni-hamburg. de/checklists/brazil_1.htm. Acessed on 11.06.2004.

Marcelli, M.P. \& Ribeiro, C.H. 2002. Twenty-one new species of Parmeliaceae (lichenized fungi) from southeastern Brazil. Mitteilungen aus dem Institut für Allgemeine Botanik in Hamburg 30-32:125-155.

Marcelli, M.P., Canêz, L.S., Benatti, M.N., Spielmann, A.A., Jungbluth, P. \& Elix, J.A. 2011. Taxonomical novelties in Parmeliaceae. Bibliotheca Lichenologica 106:211-224.

Nash, T.H. \& Elix, J.A. 2002. Canoparmelia. In Lichens Unlimited: Lichen flora of the greater Sonoran Desert Region (T.H. Nash, B.D. Ryan, P. Diederich, C. Gries \& F. Bungartz, eds.). Arizona State University, Tempe, v. 2, p. 122-125.

Rio Grande do Sul. 1996. Plano de Manejo Parque Estadual de Itapuã. Departamento de Recursos Naturais Renováveis, Porto Alegre. $126 \mathrm{p}$.

Roesch, L. F. W. Vieira, F. C. B., Pereira, V. A., Schünemann A. L., Teixeira, I. F., Senna A. J. T. \& Stefenon, V. M. The Brazilian Pampa: A Fragile Biome. Diversity, 1: 182-198, 2009.

Spielmann, A.A. \& Marcelli, M.P. 2008. Parmeliaceae (Ascomycota liquenizados) nos barrancos e peraus da encosta da Serra Geral, Vale do Rio Pardo, Rio Grande do Sul, Brasil. II. Gêneros Canoparmelia, Hypotrachyna, Myelochroa, Parmelinopsis e Relicina. Iheringia, Série Botânica 63:193-212. 